\title{
Correlation trends for bone mineral density in Mexican women:
Evidence of familiar predisposition
}

\author{
Eduardo Lazcano-Ponce, Dr Sc, (') Juan Tamayo, MD, (2) Rodrigo Díaz, PhD, (1) \\ Ana I. Burguete, Dr Sc, ${ }^{(1)}$ jorge Salmerón, Dr Sc. (3)
}

\author{
Lazcano-Ponce E, Tamayo J, Díaz R, Burguete Al, Salmerón J. \\ Correlation trends for bone mineral density \\ in Mexican women: Evidence of familiar predisposition. \\ Salud Publica Mex 2009;5 I suppl I:S93-S99.
}

\begin{abstract}
Objective. Genetic factors determine bone mineral density (BMD) and peak bone density between 20 and 30 years of age, as well as bone mineral loss after menopause. BMD is a predictor of fractures due to osteoporosis and the impact of genetic factors on osteoporosis. The variation in BMD for each individual is determined by an underlying genetic structure, common genetic effects, particularly with respect to compact bones as compared to those that are primarily trabecular. This article presents the correlation of BMD by anatomical site among different samples of Mexican grandmothers, mothers and granddaughters of mixed race. Material and Methods. The present analysis was performed of healthy employees and their healthy relatives from three different health and academic institutions: the Instituto Mexicano del Seguro Social and the Instituto Nacional de Salud Pública, both located in Cuernavaca, Morelos, as well as the Universidad Autónoma del Estado de México. We selected family-related female participants in order to obtain pairs of mothers and daughters and, whenever possible, grandmother-mother-daughter groups. We were able to match 591 mother-daughter pairs for analysis. Additionally, we were able to include grandmothers to create grandmother-motherdaughter triads for further analysis. Bone density measurements were performed of the non-dominant proximal femur, the lumbar spine (LI-L4) and the whole body using a dual X-ray absorptiometry (DXA) Lunar DPX NT instrument. Results. This study included 59I granddaughters, 591 mothers and 69 grandmothers; mean ages were 20,47 and 72 years
\end{abstract}

Lazcano-Ponce E, Tamayo J, Díaz R, Burguete Al, Salmerón J. Tendencias de correlación para la densidad mineral ósea en mujeres mexicanas: pruebas de predisposición familiar. Salud Publica Mex 2009;5I supl I:S93-S99.

\section{Resumen}

Objetivo. Factores genéticos determinan la densidad mineral ósea (DMO) y el pico máximo de masa ósea entre los 20 y 30 años de edad, así como la pérdida de densidad mineral ósea después de la menopausia. La DMO es un predictor de fracturas debido a osteoporosis y el impacto de factores genéticos sobre esta. La variación en DMO para cada individuo es determinada genéticamente, en particular en lo que concierne a huesos compactos en comparación con aquellos que son principalmente trabeculares. Este artículo presenta la correlación de DMO por sitio anatómico entre abuelas, madres y nietas mexicanas. Material y Métodos. El presente análisis fue realizado en empleados sanos y sus familiares sanos de tres diferentes instituciones de salud e instituciones académicas: el Instituto Mexicano del Seguro Social, Instituto Nacional de Salud Pública, ambos localizados en Cuernavaca, Morelos, así como la Universidad Autónoma del Estado de México. Seleccionamos a participantes femeninos relacionados para obtener los pares de madres e hijas y siempre que fuera posible a las abuelas. Nos fue posible recolectar 591 pares de madre-hija para el análisis. Además de incluir a abuelas para crear tríadas abuela-madre-hija para el análisis. Las medidas de densidad ósea fueron realizadas del fémur proximal no dominante, espina lumbar (LI-L4) y DMO total mediante el instrumento DPX DXA Lunar NT. Resultados. Este estudio incluyó a 59I nietas, 59I madres y 69 abuelas; la edad promedio fue 20,47 y 72 años. Hay una relalción entre el índice de masa corporal (BMI) entre madres y abuelas de 27.9 contra 27.3. La proporción mayor de masa

(I) Centro de Investigación en Salud Poblacional. Instituto Nacional de Salud Pública. Cuernavaca Morelos, México.

(2) Comité Mexicano para la Prevención de la Osteoporosis A,C., México Distrito Federal.

(3) Unidad de Investigación Epidemiológica y en Servicios de Salud, Instituto Mexicano del Seguro Social. Cuernavaca Morelos, México.

Received on: November 3,2008 - Accepted on: December II, 2008

Address reprint requests to: Dr. Eduardo Lazcano Ponce. Instituto Nacional de Salud Pública. Av. Universidad \# 655 Col. Sta. María Ahuacatitlán. 62508 Cuernavaca, Mor., México.

E-mail: elazcano@insp.mx 
old, respectively. A close relationship existed with respect to body mass index (BMI) between mothers and grandmothers (27.9 vs. 27.3). The largest proportion of body fat mass was observed in the group of mothers (28.5\%), but was also high in grandmothers $(25.7 \%)$ and granddaughters (21.1\%). The percentage of lean body mass was similar among the three family groups. The correlation of BMD between mothers and grandmothers was greatest for subtotal BMD $(0.44)$ and was very high for the hips (0.39). Using predictive models for hip BMD among grandmothers, mothers and grandchildren, we observed that hip BMD of grandmothers is a predictor of BMD in mothers, with a beta of 0.46 (p 0.001 , C195\% 0.19$0.73) ;\left(R^{2}: 0.4 I\right)$. A predictor of BMD of the lumbar spine in grandchildren is BMD of the lumbar spine in mothers (beta 0.30 C195\% 0.07-0.53). Conclusions. The results obtained in this study suggest that daughters whose mothers have a low BMD for their age will tend to develop the same condition. This indicates the importance of monitoring for girls and adolescent females whose mothers have problems related to osteopenia or osteoporosis. It will therefore be necessary to conduct studies to identify the most significant genes and specific anatomical sites among our population for the purpose of establishing the polymorphic variants for high-risk in the Mexican population.

Key words: bone mineral density; familiar predisposition; mixed-race; Mexico grasa de cuerpo fue observada en el grupo de madres (el $28.5 \%$ ), pero también se observó alto en abuelas (el $25.7 \%$ ) y nietas (el $21.1 \%$ ). El porcentaje de masa magra fue similar entre los tres grupos. La correlación mayor de DMO entre madres y abuelas fue para el DMO subtotal (0.44), y para caderas (0.39). Usando modelos predictivos para DMO de cadera entre abuelas, madres y nietas, observamos que la DMO de cadera de abuelas es un predictor de DMO en las hijas, con un coeficiente beta de 0.46 (p 0.00I, Cl95 el \% 0.19-0.73); (R2: $0.4 \mathrm{I})$. Un predictor de DMO de espina lumbar en las nietas es la DMO de espina lumbar en las madres (beta $0.30 \mathrm{Cl} 95 \%$ 0.07-0.53). Conclusiones. Los resultados obtenidos en este estudio sugieren que las hijas de madres con DMO bajo para su edad tenderán a la misma condición. Esto indica la importancia de vigilancia en jóvenes y mujeres adolescentes cuyas madres tengan osteopenia u osteoporosis. Por lo tanto, será necesario conducir estudios para identificar los genes más significativos por sitio anatómico específicos, para la identificación de las variantes polimórficas de riesgo en la población mexicana.

Palabras claves: densidad mineral ósea; predisposición familiar; mestizos; México
$\mathrm{B}_{\mathrm{s}}^{\mathrm{o}}$ one mineral density is greatly influenced by genetic actors as compared to environmental ones. ${ }^{1}$ Previous studies have suggested that the hereditary nature of bone density in women has two main components, one related with peak bone density reached at early ages and the other with the loss of bone density during menopause. ${ }^{2}$ Bone mineral density (BMD) and the size of the bone have been widely studied as the main determinants of osteoporosis and, consequently, of risk of fractures, but there has been little exploration as to the prognostic value of heredity, 3,4 which could potentially be applied to the prevention of the disease. Age at menarche influences BMD and both variables are phenotypically and genetically determined., ${ }^{5,6}$ Notable differences exist with respect to the effect of bone mineralization as a function of age when various ethnic groups are studied that have similar lifestyles, which is significantly explained by genetic influence. ${ }^{7}$ Genetic factors determine BMD and peak bone density between 20 and 30 years of age and bone mineral loss after menopause. ${ }^{8} \mathrm{BMD}$ is a predictor of fractures due to osteoporosis and the impact of genetic factors for this nosological group is not yet well-defined. Nevertheless, variations in BMD in each individual is caused by an underlining genetic structure, common genetic effects, ${ }^{9}$ particularly with regard to compact bones as compared to those that are primarily trabecular. In addition, BMD at different anatomical sites may be determined by type-specific genetic factors, those that are clinically influenced and expressed by environmental factors.$^{10}$ Evidence exists that the greatest variability in BMD, influenced by genetic factors, is observed in the lumbar spine and hips. ${ }^{11,12}$ Osteoporosis is one of the main causes of disability among adults and numerous factors have been described to determine associated factors, among which hereditary factors have had the strongest association. Studies in families and twins have found a strong genetic component in the determination of BMD, but the hereditary element is not sufficiently understood, ${ }^{13}$ particularly with respect to polygenetic factors. ${ }^{14}$ This article presents the correlation of BMD by anatomical site among triad groups of Mexican grandmothers, mothers and granddaughters.

\section{Methods}

\section{Study population}

The present analysis was performed among healthy employees and their healthy relatives from three different health and academic institutions: the Instituto Mexicano 
del Seguro Social and the Instituto Nacional de Salud Públi$\mathrm{ca}$, both located in Cuernavaca, Morelos, as well the Universidad Autónoma del Estado de México, located in Toluca, in the state of Mexico during January 2006 to January 2007. Subjects recruited for the study were participating in the first stage of an on going, long-term cohort study focusing on lifestyle and health. A total of 8307 adults were formally enrolled. Those participants who were parents of children 7 to 22 years of age were also asked to invite their children to be part of the study. Of those willing to participate, 1639 youths were formally invited and enrolled in the study. In order to examine the correlation between relatives grandmother, mother and daughters, we selected family-related female participants in order to obtain mother-daughter pairs and, whenever possible, grandmother-mother-daughters groups. We were able to match 591 pairs of mother and daughters for analysis. Additionally, we were able to include grandmothers to create grandmother-motherdaughters triads for further analysis. All the participants sign a consent informed, and the project was evaluated and approved by research and ethics committees of the participant institutions.

\section{BMD assessment}

Bone density measurements were performed of the nondominant proximal femur, the lumbar spine (L1-L4) and the whole body using a dual X-ray absorptiometry (DXA) Lunar DPX NT instrument. User manual instructions and International Society of Clinical Densitometry procedures were strictly followed. Standardized densitometry technicians performed all BMD measurements. Standard calibration of instruments was performed daily using the phantom provided by the manufacturer; technicians ensured that the daily variation coefficient (VC) was within normal operational standards and that the in vivo $\mathrm{VC}$ was lower than $1.5 \%$. BMD results obtained by the DXA are expressed as grams of hydroxyapatite per square centimeter.

\section{Results}

This study included 591 granddaughters, 591 mothers and 69 grandmothers; mean age was 20, 47 and 72 years old, respectively. A close correlation existed with respect to body mass index (BMI) between mothers and grandmothers (27.9 vs. 27.3). The greatest proportion of body fat mass was observed in the group of mothers $(28.5 \%)$, but it was also high in grandmothers $(25.7 \%)$ and granddaughters $(21.1 \%)$. The percentage of lean body mass was similar among the three family groups (Table I). The correlation of BMD between mothers and grandmothers was greatest for subtotal BMD (0.44); in addition, BMD of the hips was very high among mothers and granddaughters (0.39) (Table II-1).

Table I

DESCRIPTION OF THE STUDY POPULATION

\begin{tabular}{|c|c|c|c|c|c|c|c|c|}
\hline & \multirow[t]{2}{*}{ Statistics } & \multirow[t]{2}{*}{ Age } & \multirow[t]{2}{*}{$\begin{array}{c}\text { Body } \\
\text { mass index }\end{array}$} & \multirow{2}{*}{$\begin{array}{c}\text { Total } \\
\text { fat mass } \\
\S \mathrm{Kg}\end{array}$} & \multirow[t]{2}{*}{$\begin{array}{c}\text { Total } \\
\text { lean mass }\end{array}$} & \multicolumn{3}{|c|}{ Bone Mineral density $\left(\mathrm{g} / \mathrm{cm}^{2}\right)$} \\
\hline & & & & & & Spinal column & Hips & Subtotal* \\
\hline \multirow[t]{4}{*}{ Granddaughters } & $\mathrm{N}$ & 591 & 590 & 590 & 590 & 590 & 590 & 591 \\
\hline & Mean & 19 & 22.9 & 21.1 & 31.5 & I.01 & 0.99 & 1.09 \\
\hline & Standard Dev. & 8.1 & 4.9 & 9.3 & 5.6 & 0.15 & 0.14 & 0.12 \\
\hline & Std. Error & 0.3 & 0.2 & 0.3 & 0.2 & 0.006 & 0.006 & 0.005 \\
\hline
\end{tabular}

\begin{tabular}{|c|c|c|c|c|c|c|c|c|}
\hline Mothers & $\mathrm{N}$ & 591 & 590 & 590 & 590 & 590 & 584 & 590 \\
\hline & Mean & 47 & 27.9 & 28.5 & 34.9 & 1.06 & 1.01 & 1.14 \\
\hline & Standard Dev. & 9.7 & 4.7 & 8.4 & 4.3 & 0.13 & 0.14 & 0.10 \\
\hline & Std. Error & 0.4 & 0.2 & 0.3 & 0.1 & 0.005 & 0.006 & 0.004 \\
\hline
\end{tabular}

\begin{tabular}{lllllrrrrr} 
Grandmothers & $\mathrm{N}$ & 69 & 69 & 69 & 69 & 69 & 69 & 0.88 & 0.84 \\
\hline & Mean & 72 & 27.3 & 25.7 & 33.2 & 0.97 & 0.10 & 0.13 & 0.09 \\
\hline & Standard Dev. & 6.9 & 4.7 & 7.9. & 4.2 & 0.10 & 0.01 & 0.01
\end{tabular}

* subtotal $\mathrm{BMD}=$ Total BMD minus head BMD

‡ Body Mass Index $=$ Weight $(\mathrm{kg}) /$ height $^{2}(\mathrm{~m})$

$\S$ Using densitometry 
A high correlation of subtotal BMD $(0.26)$ between mothers and granddaughters was present; nevertheless, the highest correlation index was observed between BMD of the spinal column in mothers and BMD of the hips in granddaughters (Pearson correlation 0.30). Finally, the Pearson correlation between grandmothers and granddaughters was high for subtotal BMD (34.6), the BMD of the spinal column (30.0) and the hips (31.0), as shown in Table II. These correlation models in the three anatomical sites and among grandmothers, mothers and granddaughters can also be seen in Figure 1.

Using predictive models for BMD of the hips among grandmothers, mothers and granddaughters, we observed that BMD of the hips in grandmothers is a predictor of BMD in mothers, with a beta of $0.46(p=$ 0.001, CI95\% 0.19-0.73); $\left(\mathrm{R}^{2}=0.41\right)$.

With respect to mothers and granddaughters, the correlation was not significant (beta $=0.19$, CI95\% -0.08 - 0.45) (Table III-3).

Finally, the correlation of BMD of the hips between grandmothers and granddaughters was not significant (beta $=0.24$, C195\% -0.04-0.51), as seen in Table III-2.

In Tables III-4, 5 and 6, predictive models for $\mathrm{BMD}$ of the lumbar spine in grandmothers, mothers and granddaughters are shown. A predictor of BMD in the lumbar spine in granddaughters is BMD of the lumbar spine in mothers (beta $=0.30$ CI95\% 0.07-0.53). In addition, no statistically significant correlation existed between grandmothers and mothers and between grandmothers and granddaughters.

In predictive models for total BMD (except the head) in grandmothers, mothers and granddaughters, there was a close correlation of total BMD (except the head) between grandmothers and mothers (beta 0.32, C195\% 0.070-0.58 ) independent of age, with a high level of prediction ( $\left.\mathrm{R}^{2}: 0.45\right)$. This correlation was also observed between mothers and granddaughters, with a beta value of 0.33 (CI95\% 0.06-0.60), as well as between grandmothers and granddaughters, with a beta of 0.34 (CI95\% 0.07-0.61), as shown in Table III-7, 8 and 9.

\section{Discussion}

In our triad of Mexican grandmothers, mothers and granddaughters, we observed a high correlation of BMD among the three generations, which indicates an enormous genetic influence on bone mineralization. Body composition trends are transmitted from mothers to

Table II

MATRIX FOR THE CORRELATION OF BMD

BY DIFFERENT ANATOMICAL SITES

1. Grandmothers-mothers

BMD hips (grandmothers) BMD Spinal column (grandmothers) Total BMD (grandmothers)

\begin{tabular}{llll} 
Hips (mothers) & $0.39^{*}$ & $0.23 * *$ & $0.23 * *$ \\
\hline Spinal column (mothers) & $0.34^{*}$ & $0.26 * *$ & $0.3 I^{*}$ \\
\hline Subtotal (mothers) & $0.39^{*}$ & $0.33^{*}$ & $0.44^{*}$
\end{tabular}

2. Grandmothers - granddaughters

BMD hips (grandmothers) BMD Spinal column (grandmothers) Total BMD (grandmothers)

\begin{tabular}{llll} 
Hips (granddaughters) & $0.31^{* *}$ & $0.27^{* *}$ & $0.35^{*}$ \\
\hline Spinal column (granddaughters) & 0.21 & $0.30^{* *}$ & $0.35^{*}$ \\
\hline Subtotal (granddaughters) & 0.20 & $0.24^{* *}$ & $0.34^{*}$
\end{tabular}

3. Mothers - granddaughters

\begin{tabular}{lccc}
\hline & BMD hips (mothers) & BMD Spinal column (mothers) & Total BMD (mothers) \\
Hips (granddaughters) & 0.18 & $0.30^{* *}$ & $0.24^{* *}$ \\
\hline Spinal column (granddaughters) & 0.07 & $0.24^{* *}$ & $0.25^{* *}$ \\
\hline Subtotal (granddaughters) & 0.01 & $0.24^{* *}$ & $0.26 * *$
\end{tabular}

$P$ value: $*<0.001 * *<0.05$ 

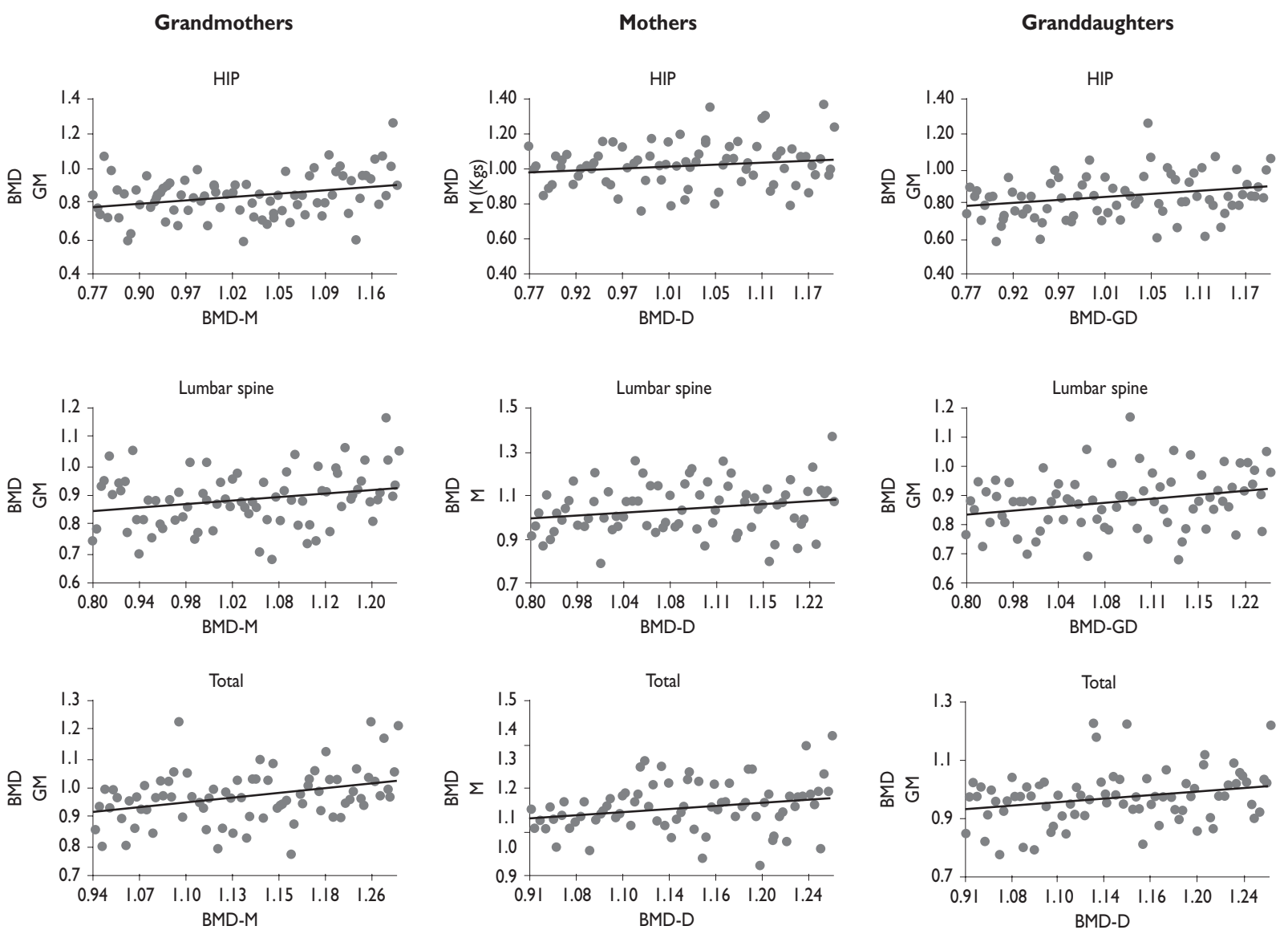

BMD M - BMD Mothers $\left(\mathrm{g} / \mathrm{cm}^{2}\right)$

BMD D - BMD Daughters $\left(\mathrm{g} / \mathrm{cm}^{2}\right)$

BMD GM - BMD Granddaughters $\left(\mathrm{g} / \mathrm{cm}^{2}\right)$

BMS-GM - BMD Grandmothers $\left(\mathrm{g} / \mathrm{cm}^{2}\right)$

Figure I. Correlation of BMD AMONG GRANDMOtherS-MOthers-GRANDDAUGHTERS

daughters, and although this factor could be influenced by hereditary factors, it is important to consider the fact that lifestyle characteristics are shared.

We observed a strong association of BMD of the hips between grandmothers and mothers; this association was also found between mothers and granddaughters. Nevertheless, the latter was not significant, possibly as a result of a lack of statistical power. This correlation of BMD among generations could be explained by factors such as dietary and lifestyle habits; findings of differences in prediction among different anatomical sites suggest the influence of genetic factors. Diverse studies have described the importance of genetic determination on BMD. ${ }^{8,15-19}$

In 1999, Francois S et al., and Mitchell et al. in 2003, reported that the children of mothers with a familiar history of osteoporosis presented a decrease in BMD for their age. 8,20 This finding suggests that BMD presents a hereditable trend among generations, which is explained by genetic predisposition and its interaction with environmental factors. This is reflected in our study when observing the strong correlation among direct descendents which, though it continues to be positive, decreases for the second generation.

Another important finding in our study is the high prediction of BMD in women belonging to the group of granddaughters when evaluating subtotal BMD among the three generations. Nevertheless, when stratifying by anatomical site, the effect is different for the lumbar spine and hips, which strengthens the hypothesis of genetic predisposition mediated by a pleiotropical effect of genes associated with BMD. The fact that the 
Table III

Predictive models of BMD among GRANDMOthers, MOthers AND DAUGHTERS

\begin{tabular}{|c|c|c|c|c|c|c|c|c|c|c|c|c|c|c|c|c|c|}
\hline \multicolumn{6}{|c|}{ I Dependent variable Hip BMD (Mothers) } & \multicolumn{6}{|c|}{ 4.Dependent Variable: Spinal column BMD (Mothers) } & \multicolumn{6}{|c|}{ 7.Dependent Variable: Subtotal BMD (Mothers) } \\
\hline & B & SE & P & $\mathrm{C} 195 \%$ & & & B & SE & $P$ & \multicolumn{2}{|l|}{$\mathrm{Cl} 195 \%$} & & \multirow[t]{2}{*}{ B } & \multirow[t]{2}{*}{ SE } & \multirow[t]{2}{*}{ P } & \multirow{2}{*}{\multicolumn{2}{|c|}{$\begin{array}{l}\mathrm{Cl} 95 \% \\
\text { Low High }\end{array}$}} \\
\hline & & & & Low & High & & & & & Low & High & & & & & & \\
\hline Constant & 0.52 & 0.27 & 0.06 & -0.01 & 1.06 & Constant & 1.14 & 0.24 & 0.00 & 0.66 & 1.61 & Constant & 0.87 & 0.19 & 0.00 & 0.48 & 1.26 \\
\hline $\begin{array}{l}\text { Age (grandmoth- } \\
\text { ers) }\end{array}$ & 0.00 & 0.00 & 0.42 & 0.00 & 0.01 & $\begin{array}{l}\text { Age (grandmo- } \\
\text { thers) }\end{array}$ & 0.00 & 0.00 & 0.02 & -0.01 & 0.00 & Age (grandmothers) & 0.00 & 0.00 & 0.55 & 0.00 & 0.00 \\
\hline $\begin{array}{l}\text { Hip BMD (grand- } \\
\text { mothers) }\end{array}$ & 0.46 & 0.14 & 0.00 & 0.19 & 0.74 & $\begin{array}{l}\text { Spinal column } \\
\text { BMD (grandmo- } \\
\text { thers) }\end{array}$ & 0.27 & 0.16 & 0.10 & -0.06 & 0.59 & $\begin{array}{l}\text { Subtotal BMD } \\
\text { (grandmothers) }\end{array}$ & 0.33 & 0.13 & 0.01 & 0.07 & 0.58 \\
\hline $\begin{array}{l}\text { Fat mass (grand- } \\
\text { mothers) }\end{array}$ & 0.00 & 0.00 & 0.72 & 0.00 & 0.00 & $\begin{array}{l}\text { Fat mass (grand- } \\
\text { mothers) }\end{array}$ & 0.00 & 0.00 & 0.96 & 0.00 & 0.00 & $\begin{array}{l}\text { Fat mass (grandmo- } \\
\text { thers) }\end{array}$ & 0.00 & 0.00 & 0.62 & 0.00 & 0.00 \\
\hline \multirow{2}{*}{$\begin{array}{l}\text { BMI (grandmoth- } \\
\text { ers) }\end{array}$} & 0.00 & 0.01 & 0.93 & -0.02 & 0.02 & $\begin{array}{l}\text { BMI (grandmo- } \\
\text { thers) }\end{array}$ & 0.00 & 0.01 & 0.86 & -0.01 & 0.02 & BMI (grandmothers) & 0.00 & 0.01 & 0.83 & -0.01 & 0.01 \\
\hline & $R=0.413$ & $R^{2}=0.170$ & & & & & $R=0.403$ & $R^{2}=0.162$ & & & & & $R=0.459$ & $R^{2}=0.210$ & & & \\
\hline \multicolumn{6}{|c|}{ 2.Dependent Variable: Hip BMD (Daughters) } & \multicolumn{6}{|c|}{ 5.Dependent Variable: Spinal Column BMD (Daughters) } & \multicolumn{6}{|c|}{ 8.Dependent Variable: Subtotal BMD (Daughters) } \\
\hline & B & SE & $\mathrm{P}$ & $\mathrm{C} 195 \%$ & & & B & SE & $\mathrm{P}$ & $\mathrm{C} 195 \%$ & & & B & SE & $P$ & $\mathrm{Cl} 195 \%$ & \\
\hline & & & & Low & High & & & & & Low & High & & & & & Low & High \\
\hline Constant & 0.95 & 0.27 & 0.00 & 0.42 & 1.49 & Constant & 0.70 & 0.23 & 0.00 & 0.24 & 1.17 & Constant & 0.73 & 0.20 & 0.00 & 0.32 & 1.13 \\
\hline $\begin{array}{l}\text { Age (grandmoth- } \\
\text { ers) }\end{array}$ & 0.00 & 0.00 & 0.72 & -0.01 & 0.00 & $\begin{array}{l}\text { Age (grandmo- } \\
\text { thers) }\end{array}$ & 0.00 & 0.00 & 0.65 & 0.00 & 0.00 & $\begin{array}{l}\text { Age (grandmo- } \\
\text { thers) }\end{array}$ & 0.00 & 0.00 & 0.45 & 0.00 & 0.00 \\
\hline $\begin{array}{l}\text { Hip BMD (grand- } \\
\text { mothers) }\end{array}$ & 0.24 & 0.14 & 0.09 & -0.04 & 0.51 & $\begin{array}{l}\text { Spinal column } \\
\text { BMD (grandmo- } \\
\text { thers) }\end{array}$ & 0.30 & 0.16 & 0.07 & -0.02 & 0.62 & $\begin{array}{l}\text { Subtotal BMD } \\
\text { (grandmothers) }\end{array}$ & 0.35 & 0.13 & 0.01 & 0.08 & 0.61 \\
\hline $\begin{array}{l}\text { Fat mass (grand- } \\
\text { mothers) }\end{array}$ & 0.00 & 0.00 & 0.32 & 0.00 & 0.00 & $\begin{array}{l}\text { Fat mass (grand- } \\
\text { mothers) }\end{array}$ & 0.00 & 0.00 & 0.97 & 0.00 & 0.00 & $\begin{array}{l}\text { Fat mass (grandmo- } \\
\text { thers) }\end{array}$ & 0.00 & 0.00 & 0.81 & 0.00 & 0.00 \\
\hline \multirow[t]{2}{*}{$\begin{array}{l}\text { BMI (grandmoth- } \\
\text { ers) }\end{array}$} & -0.01 & 0.01 & 0.40 & -0.02 & 0.01 & $\begin{array}{l}\text { BMI (grandmo- } \\
\text { thers) }\end{array}$ & 0.00 & 0.01 & 0.76 & -0.01 & 0.02 & BMI (grandmothers) & 0.00 & 0.01 & 0.89 & -0.01 & 0.01 \\
\hline & $R=0.337$ & $\mathrm{R}^{2}=0.114$ & & & & & $\mathrm{R}=0.321$ & $R^{2}=0.103$ & & & & & $R=0.361$ & $R^{2}=0.130$ & & & \\
\hline \multicolumn{6}{|c|}{ 3.Dependent Variable: Hip BMD (Daughters) } & \multicolumn{6}{|c|}{ 6.Dependent Variable: Spinal Column BMD (Daughters) } & \multicolumn{6}{|c|}{ 9.Dependent Variable: Subtotal BMD (Daughters) } \\
\hline & B & SE & P & $\mathrm{C} 195 \%$ & & & B & SE & $P$ & $\mathrm{C} 195 \%$ & & & B & SE & $P$ & $\mathrm{Cl} 195 \%$ & \\
\hline & & & & Low & High & & & & & Low & High & & & & & Low & High \\
\hline Constant & 0.86 & 0.18 & 0.00 & 0.49 & 1.23 & Constant & 0.49 & 0.18 & 0.01 & 0.13 & 0.86 & Constant & 0.65 & 0.18 & 0.00 & 0.29 & 1.02 \\
\hline Age (mothers) & 0.00 & 0.00 & 0.98 & 0.00 & 0.00 & $\begin{array}{l}\text { Age } \\
\text { (mothers) }\end{array}$ & 0.00 & 0.00 & 0.03 & 0.00 & 0.01 & Age (mothers) & 0.00 & 0.00 & 0.13 & 0.00 & 0.01 \\
\hline $\begin{array}{l}\text { Hip BMD } \\
\text { (mothers) }\end{array}$ & 0.19 & 0.13 & 0.17 & -0.08 & 0.45 & $\begin{array}{l}\text { Spinal column } \\
\text { BMD (mothers) }\end{array}$ & 0.30 & 0.12 & 0.01 & 0.07 & 0.53 & $\begin{array}{l}\text { Subtotal BMD } \\
\text { (mothers) }\end{array}$ & 0.34 & 0.14 & 0.02 & 0.06 & 0.61 \\
\hline $\begin{array}{l}\text { Fat mass } \\
\text { (mothers) }\end{array}$ & 0.00 & 0.00 & 0.82 & 0.00 & 0.00 & $\begin{array}{l}\text { Fat mass (mo- } \\
\text { thers) }\end{array}$ & 0.00 & 0.00 & 0.70 & 0.00 & 0.00 & $\begin{array}{l}\text { Fat mass } \\
\text { (mothers) }\end{array}$ & 0.00 & 0.00 & 0.72 & 0.00 & 0.00 \\
\hline \multirow[t]{2}{*}{ BMI (mothers) } & 0.00 & 0.01 & 0.81 & -0.02 & 0.01 & $\begin{array}{l}\text { BMI } \\
\text { (mothers) }\end{array}$ & 0.00 & 0.01 & 0.50 & -0.01 & 0.02 & BMI (mothers) & 0.00 & 0.00 & 0.83 & -0.01 & 0.01 \\
\hline & $R=0.189$ & $R^{2}=0.036$ & & & & & $R=0.375$ & $R^{2}=0.141$ & & & & & $\mathrm{R}=0.323$ & $R^{2}=0.104$ & & & \\
\hline
\end{tabular}

bone of the spinal column is made up of both cortical as well as trabecular bone and the hips are primarily trabecular explains how the correlation found in our study reflects a genetically determined osteoporosis phenotype dependent on the anatomical site, where at the femoral level there is an association with chromosome $21 \mathrm{q}$ and with chromosome $14 \mathrm{q} 31$ at the lumbar spine. ${ }^{12,21}$ The intergenerational correlation of subtotal BMD by specific anatomical site supports the hypothesis that a significant genetic component is involved. These findings are consistent with various reports that associate diverse gene polymorphisms with BMD regulation. Genetic influence determines a lower peak bone density in individuals with a familiar history of osteoporosis; numerous genes have been identified as determinants of bone density, among which are those that code for the vitamin $\mathrm{D}$ receptor, the estrogen receptor, type 1 collagen, IGF1, TGF-beta and BMPs. ${ }^{5-8,22-24}$

A recent report of a high resolution linkage study and the evaluation of linkage disequilibrium for SNPs on chromosome 1 p36 in 39 pedigrees with osteoporosis identifies new gene candidates associated with low bone mineral density in distinct anatomical sites. The genes identified in this study include RERE (SNP rs11121179 $p=0.000005$ ) for the spinal column, G1P2, SSU72 and CCDC27. ${ }^{25}$

Although the present study does not evaluate genetic determinants, it provides important evidence to establish that the risk of osteoporosis, as measured by BMD, presents a model particular to heredity that enables the prediction of risk in young women of developing osteoporosis in adulthood. The fact that an intergenerational association of BMD is observed substantiates the potential effect of common genes at the different anatomical sites that would be regulating bone metabolism.

\section{Conclusions}

The results obtained in this study suggest that daughters of women with low BMD for their age will tend to have the same condition. This indicates the importance of 
monitoring girls and female adolescents whose mothers have problems with osteopenia or osteoporosis. Therefore, it will be necessary to conduct studies to identify the most significant genes and the specific anatomical sites in our population to establish polymorphic variants for high-risk in the Mexican population.

Understanding the mechanisms by which genetic factors regulate BMD and other phenotypes related with osteoporosis has important implications for clinical practice. The genes that regulate BMD and bone fragility could potentially be used as diagnostic markers for the evaluation of individuals at risk for developing osteoporosis. These markers could be used along with biochemical markers and BMD evaluation to develop more specific therapies for individuals at high risk of osteoporosis.

The future identification of genes associated with osteoporosis will provide relevant information for the creation of instruments to identify high-risk individuals in a timely manner, to whom health interventions can be directed with greater effectiveness and which will surely translate into an effect on morbidity and the reduction of medical costs.

\section{References}

I.Yang TL, Zhao LJ, Liu YJ, Liu JF, Recker RR, Deng HW. Genetic and environmental correlations of bone mineral density at different skeletal sites in females and males. Calcif Tissue Int 2006 Apr;78(4):2I 2-7.

2. Lutz J, Tesar R. Mother-daughter pairs: spinal and femoral bone densities and dietary intakes. Am J Clin Nutr 1990 Nov;52(5):872-7. 3.Wang YB, Lei SF, Dvornyk V, Sun X, Jiang DK, Li MX, Deng HW.The genetic, environmental and phenotypic correlations of bone phenotypes at the spine and hip in Chinese.Ann Hum Biol 2006 Jul-Aug;33(4):500-9. 4. Deng FY, Lei SF, Li MX, Jiang C, Dvornyk V, Deng HW. Genetic determination and correlation of body mass index and bone mineral density at the spine and hip in Chinese Han ethnicity. Osteoporos Int 2006 Jan; I $7(1):$ I I 9-24.

5. Guo Y, Zhao LJ, Shen H, Guo Y, Deng HW. Genetic and environmental correlations between age at menarche and bone mineral density at different skeletal sites. Calcif Tissue Int 2005 Dec;77(6):356-60. 6. Yang YJ, Dvornyk V, Jian WX, Xiao SM, Deng HW. Genetic and environmental correlations between bone phenotypes and anthropometric indices in Chinese. Osteoporos Int 2005 Sep; I6(9): I I 34-40.

7. Bachrach LK, Hastie T,Wang MC, Narasimhan B, Marcus R. Bone mineral acquisition in healthy Asian, Hispanic, Black, and Caucasian youth: a longitudinal study.J Clin Endocrinol Metab 1999 Dec;84(I2):4702-12. 8. Brown LB, Streeten EA, Shapiro JR, McBride D, Shuldiner AR, Peyser $\mathrm{PA}$, Mitchell BD. Genetic and environmental influences on bone mineral density in pre- and post-menopausal women. Osteoporos Int 2005 Dec; 16(I2): 1849-56.
9. Peacock M, Koller DL, Fishburn T, Krishnan S, Lai D, Hui S, Johnston CC, Foroud T, Econs MJ.Sex-specific and non-sex-specific quantitative trait loci contribute to normal variation in bone mineral density in men.J Clin Endocrinol Metab 2005 May;90(5):3060-6.

10. Livshits G, Deng HW, Nguyen TV,Yakovenko K, Recker RR, Eisman JA. Genetics of bone mineral density: evidence for a major pleiotropic effect from an intercontinental study.J Bone Miner Res 2004 Jun; 19(6):914-23.

I I. Jian WX, Long JR, Li MX, Liu XH, Deng HW. Genetic determination of variation and covariation of bone mineral density at the hip and spine in a Chinese population.J Bone Miner Metab 2005;23(2): I8I-5.

12. Duncan EL, Cardon LR, Sinsheimer JS, Wass JA, Brown MA. Site and gender specificity of inheritance of bone mineral density. J Bone Miner Res 2003 Aug; |8(8): I53|-8.

13. Mitchell BD, Kammerer CM, Schneider JL, Perez R, Bauer RL. Genetic and environmental determinants of bone mineral density in Mexican Americans: results from the San Antonio Family Osteoporosis Study. Bone 2003 Nov;33(5):839-46.

14. Pelat C,Van Pottelbergh I, Cohen-Solal M, Ostertag A, Kaufman JM, Martinez M, de Vernejoul MC. Complex segregation analysis accounting for GxE of bone mineral density in European pedigrees selected through a male proband with low BMD. Ann Hum Genet 2007 Jan; 7 I (Pt I):29-42. I5. Greendale GA, Chu J, Ferrell R, Randolph JF Jr, Johnston JM, Sowers $M R$. The association of bone mineral density with estrogen receptor gene polymorphisms. Am J Med 2006; II 9 (9 Supl I): S79-86.

16.Williams FM, Spector TD. Recent advances in the genetics of osteoporosis. J Musculoskelet Neuronal Interact 2006; 6: 27-35.

17. Francois S, Benmalek A, Guaydier-Souquieres G, Sabatier JP, Marcelli C. Heritability of bone mineral density. Rev Rhum Engl Ed 1999; 66: |46-5I. 18. Runyan SM, Stadler DD, Bainbridge CN, Miller SC, Moyer- Mileur LJ. Familial resemblance of bone mineralization, calcium intake, and physical activity in early-adolescent daughters, their mothers, and maternal grandmothers. J Am Diet Assoc 2003; 103: 1320-5.

19. Tylavsky FA, Bortz AD, Hancock RL,Anderson JJ. Familial resemblance of radial bone mass between premenopausal mothers and their collegeage daughters. Calcif Tissue Int 1989; 45: 265-72.

20. Danielson ME, Cauley JA, Baker CE, Newman AB, Dorman JS, Towers $J \mathrm{D}$, et al. Familial resemblance of bone mineral density (BMD) and calcaneal ultrasound attenuation: the BMD in mothers and daughters study, J Bone Miner Res 1999; 14: 102-10.

2I. Karasik D, Myers RH, Cupples LA, Hannan MT, Gagnon DR, Herbert A, Kiel DP. Genome screen for quantitative trait loci contributing to normal variation in bone mineral density: the Framingham Study.J Bone Miner Res 2002 Sep; 17(9): 17|8-27.

22. Mezquita-Raya P, Muñoz-Torres M, de Dios Luna J, Lopez-Rodriguez F, Quesada JM, Luque-Recio F, Escobar-jiménez F. Performance of COLIAI polymorphism and bone turnover markers to identify postmenopausal women with prevalent vertebral fractures. Osteoporos Int 2002; 13(6):506-12.

23. Quesada JM, Casado A, Díaz C, Barrios L, Cuenca-Acevedo R, Dorado $\mathrm{G}$. Allele-frequency determination of Bsml and Fokl polymorphisms of the VDR gene by quantitative real-time PCR (QRT-PCR) in pooled genomic DNA samples. J Steroid Biochem Mol Biol 2004 May;89-90(I-5):209-I4. 24. Albagha OM, Ralston SH. Genetic determinants of susceptibility to osteoporosis. Endocrinol Metab Clin North Am 2003 Mar;32(I):6 25. Zhang H, Sol-Church K, Rydbeck H, Stabley D, Spotila LD, Devoto $M$. High resolution linkage and linkage disequilibrium analyses of chromosome Ip36 SNPs identify new positional candidate genes for low bone mineral density. Osteoporos Int 2008 Jul 3. 